ISSN 1991- 8690

website: http://jsci.utq.edu.iq

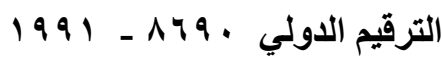

Email: utjsci@utq.edu.iq

\title{
A Study of acute toxicity to pyrethroid insecticide "KARATE" on fresh water alga Scenedesmus quadricauda (Turb.) Bereb.
}

\author{
Jasim Mohammed Salman Mayson Mahdi Saleh \\ Biology Dep.- Coll. Of Science-Babylon University-Iraq
}

\begin{abstract}
The study was conducted to evaluate the acute toxicity of insecticide (Karate) upon trough use green algae Scendesmus quadricauda as test organism in period time $(24,72,96)$ hours under control conditions. The alga was growing in water giving from Al-Hilla river after filtering by Millipore filter paper $(0.45) \mu \mathrm{m}$.

Triplicates of samples where exposed to insecticides in a different concentrations $(0.5,1,3) \mathrm{mg} / \mathrm{l}$. Monitoring was proceeded every 24 hours for four days .

This study include measure the optical density as indicators to density of algae and total count of cell number, growth average and inhibition ratio was study, also LT50 is calculated.

Result show increase concentration of insecticide with increase concentration and recorded high inhibition ratio in concentration $3 \mathrm{mg} / \mathrm{l}$ is $(91.4 \%)$ after $(96) \mathrm{h}$, and low value of LT50 in concentration (3)mg/l is (17.78).

This study pointed out that insecticide differs in their toxicity according to concentration and tim exposure.
\end{abstract}

Key words: acute toxicity ; Scenedesmus quadricauda; pyrethroid insecticides.

E.mail: jassim_hilla@yahoo.com 


\section{Introduction:}

Algae considering as being the primary producer in the aquatic environment their importance in providing energy to zooplankton and fish (Vagi et al., 2005).

Algae were used to evaluate the risk of new chemicals via laboratory research and these organisms are used to bioassays to measure the toxicity of waste water stream(Prokhotskaya et al., 2003).

A variety of organic toxic gents such as insecticides, herbicides and other organic compounds have detected in fresh water system, and effect both target and non target organisms when discharged into a water $\operatorname{body}(\mathrm{Li}$ et al.,2005).

Toxic compounds may affect on algal photosynthesis, growth, enzyme activity and respiration ; the action of toxic substance on algae is important not only for the organisms themselves, but also for other links in the food chain(Ma and Liang, 2001). Insecticides are diverse' group of widely varying chemical structure from simple inorganic to complex organic molecules, they are released in the environment by volatilization, adsorption, chemical and। or microbiological transformations( Rand,1995), their application can cause adverse effects on aquatic ecosystems in areas near by agricultural fields because those substance can be transferred to the aquatic environment leading to contamination of its flora and fauna, these contaminants may occur during rainfalls or eventually by atmospheric deposition(Vagi, et al., 2005) .

In order to evaluate the importance of this aquatic contamination it is necessary to resort to toxicity bioassays (Deneer,2000). A decrease in algae density and species richness affects the aquatic system directly by reducing their biodiversity and primary products (Abdel-Aty, et al.,2006) .

Numerous studies have indicated that pesticides inhibits growth and photosynthesis of fresh water algae and algal responses to this compounds vary widely depending upon concentration use ,duration exposure, and algale species tested (Tang et al. 1997).

Pyrethroid insecticides are relatively persistent in water, and its concentrations would not be expected to vary greatly over time specially in shortterm bioassays( Solomon et al., 1996). More recent testing procedures have recognized that, because the wide range of sensitivity

observed, a batter of species is recommended to improve algal toxicity detection in chemical evaluation(Boutin et al., 1993).

Algae species used in this bioassays Scenedesmus quadricauda was chosen in this study because easy to cultivate and its response is highly reproducible(Huang et al. 1994).

The aim of the current study was examine the effect of insecticide" Karate" on growth of green alga $S$. quadricauda and include measure of optical density as indicators to density of algae; \% inhibition ; and LT50.

\section{Materials and Methods:}

Fresh water algae $S$. quadricauda was obtained from institute of Biotechnology $\backslash$ Baghdad University-Iraq.

The test species grow in natural conditions by use water from Hilla river after sterilized and filtration by Millipore filter paper $0.45 \mu \mathrm{m}$ to released other species of algae and microorganisms as bacteria ; $\mathrm{pH}$ regulation in lab. By $\mathrm{NaOH}$ andH2SO4 ; 
Screw- capped glass tubes( $150 \mathrm{~mm} \times$ $22 \mathrm{~mm}$ diameter), each containing $30 \mathrm{ml}$ river water and $14.5 \mathrm{ml}$ from algal culture(Li et al.2005). Insecticide (Karate) solution(6\%) dissolved in water was added to each tube providing nominal concentration of $0.5,1$, and 3 $\mathrm{mg} / \mathrm{l}$.

Samples were withdrawn after 24,72, and 96 hours , each test was replicated three times.(Kent and currie,1995). From day(0) to day(4) algal cells were taken daily and cell numbers were counted with counting chamber under microscope determine the growth rate and \% inhibiting optical density was measured at $680 \mathrm{~nm}$ from each sample( Kasai et al., 1993) .

The growth rate was calculated according to the equation

( Guillard,1973):

$\mathrm{U}=\mathrm{LnNi}$-LnNol(t-to)

Where(U) is the growth rate, $(\mathrm{Ni})$ the cell number at $(\mathrm{t})$ time, (No) the cell number at o time, $t$ the sample time for counting cell number, and to is the origin time of the treatment.

The percent inhibition( $\%$ I) of algal growth for each concentration was calculated according to( U. S. EPA, 1989).

LT50 were calculated using the probate procedure with log transformed values of test insecticide concentrations.(Li,et al.,2005). The statistically significant effects of the pesticide on growth of algae species under study was determined using analysis of variance(ANOVA) with SPSS program.

\section{$\underline{\text { Results and Discussion: }}$}

The effects of the pesticide(karate) show in figures (1-4). The inhibitory effects on algal growth by optical density, it is decreased with increase the concentration of pesticide and time exposure.

The growth rate of algae measured after the exposure to pesticide by total count of cell survival reflects of cell responses to increasing concentration and inhibition in low doses and cell death in high doses( Prokhotskaya et al., 2003).

The growth of algal cell under study was highly affected by insecticide karate in the number of cells was decreased and the content of pigments and the activity of SOD were highly activity by different types of pesticide (Kong and Sang, 1999).

The effective concentrations that caused $50 \%$ inhibition compared with the controls were calculated for the algal species under study(figure 4) at (24,72, 96 )hours after treatment for optical density.

The LT50 values varied significantly among different concentrations, according to this study the $96 \mathrm{~h}$ LT50 of karate on $S$. quadricauda was (17.78) $\mathrm{mgll}$ and 72h,24 h LT50 were (22.28) and (38.48)mgll respectively.

LT50 values are useful to more exactly determine the range of pesticide concentrations that cause growth inhibition in an algal population( Anton et al . 1993).

The LT50 values ( fig. 5-7)from this study are similar to those reported for other algal species(Solomon et al., 1996).

The differential sensitivity to toxins among freshwater algae could have serious impacts on community structure and seasonal successional patterns ( Hersh and Crumpton,1987). 


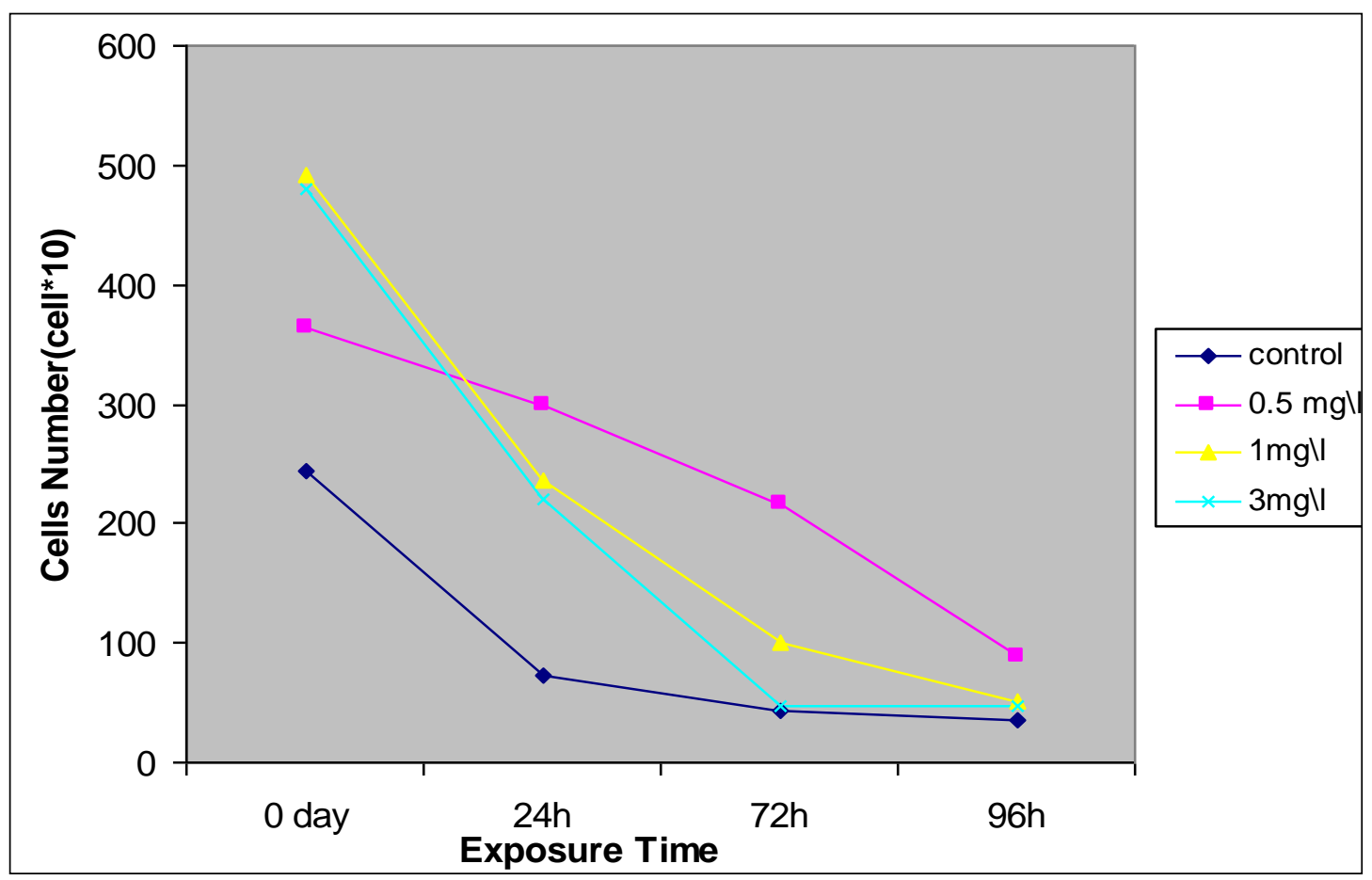

Figuer(1) Total cell number of S. quadricauda at exposure to difrente concentrations from insecticide karate

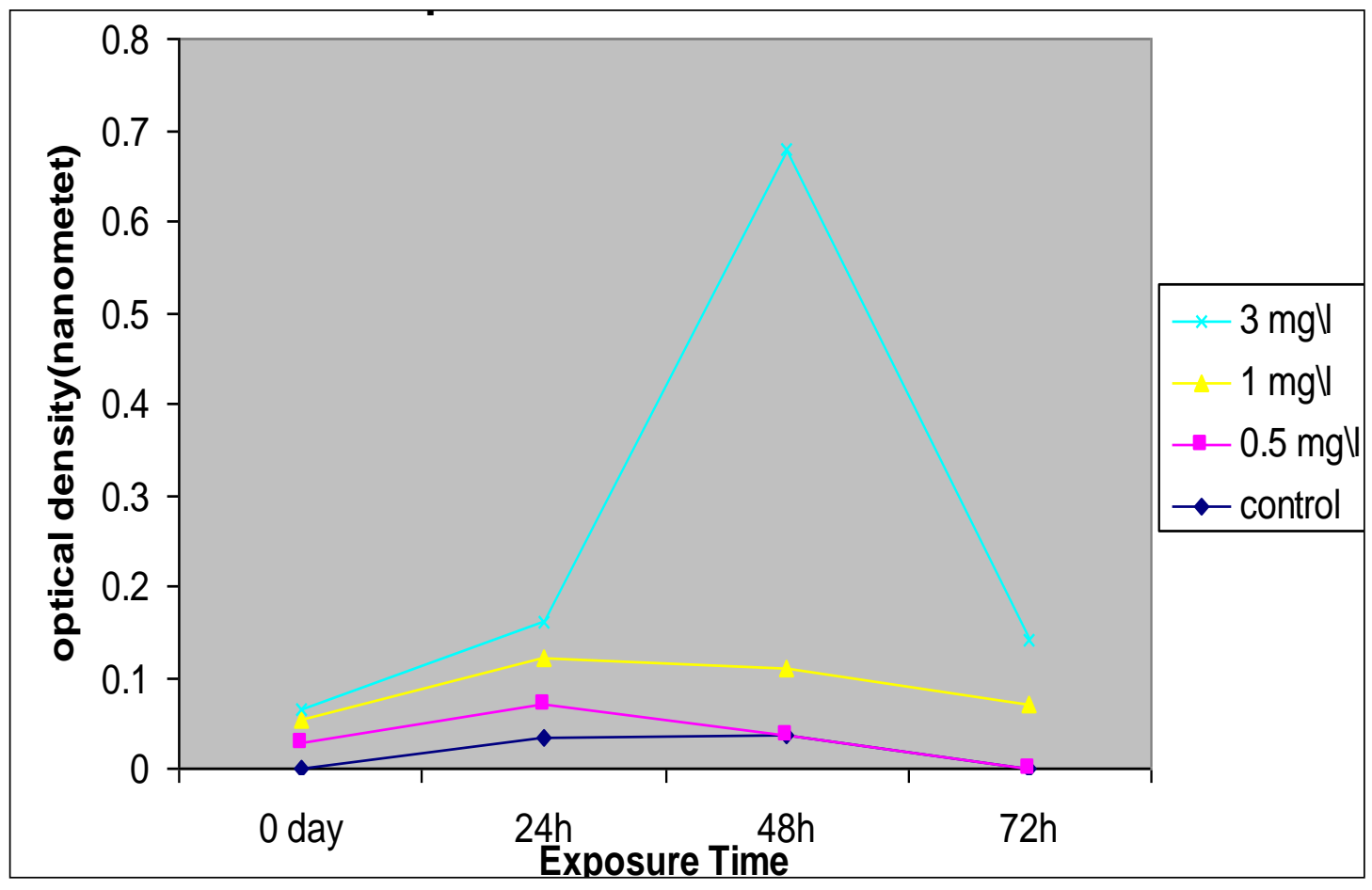

Figure(2):Optical Density of S.quadricauda after exposure to insecticide karate 


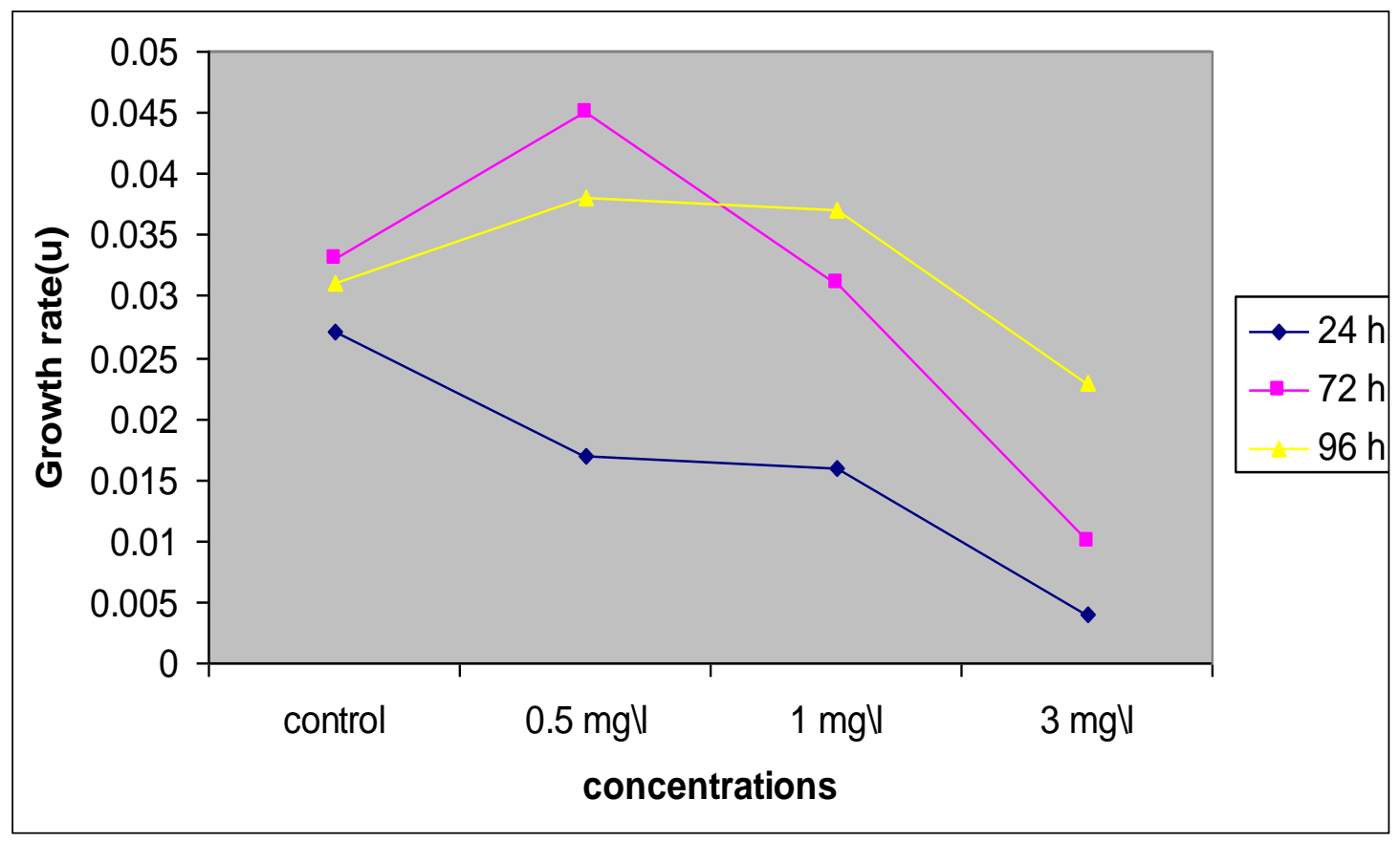

Figure(3): Growth rate of S.quadricauda at exposuer to diferent cocentrations from insecticide karate

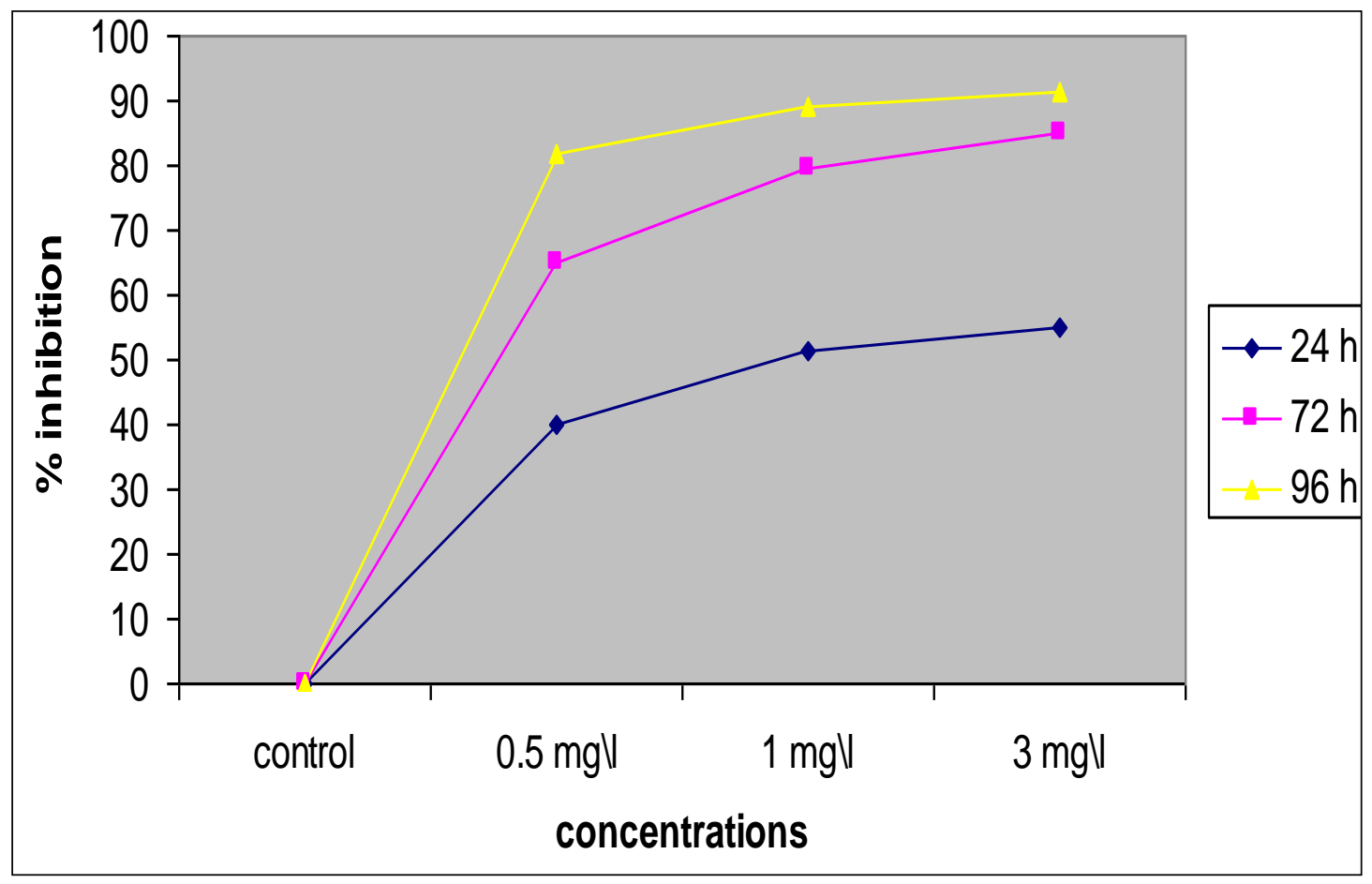

Figure(4):Inhibition rate(\%) of S. quadricauda at exposuer todifrent concentrations from insecticide karate 


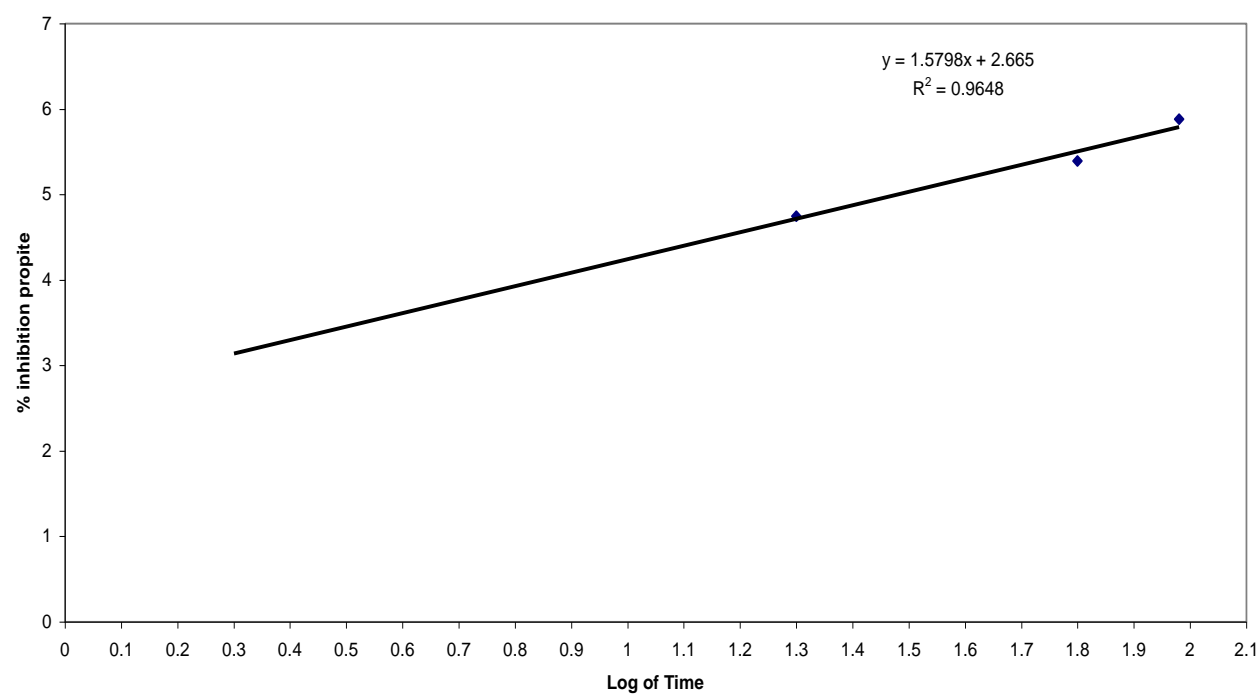

Figure( 5 ) Line of toxicity on exposure S.quadricauda to isecticide karate in concentration $(0.5) \mathrm{mg} / \mathrm{l}$ and $\mathrm{LT} 50$ value

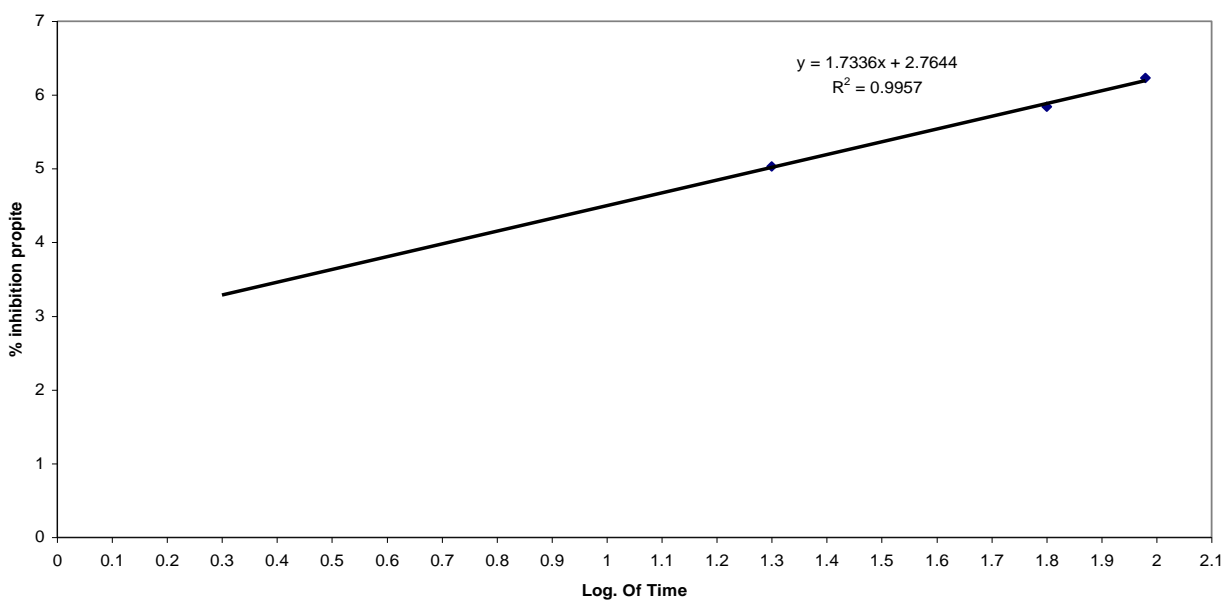

Figure( 6 )Line of toxicity on exposure S.qaudricauda to insecticide karatein concentration (1) $\mathrm{mg} / \mathrm{l}$ and $\mathrm{LT} 50$ value

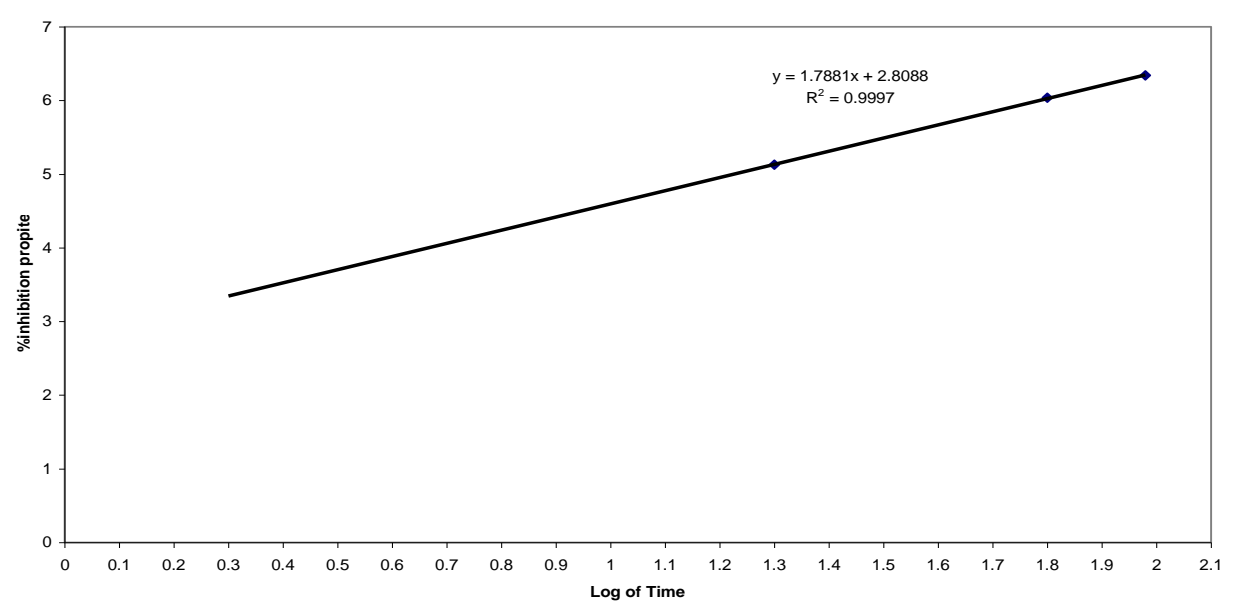

Figure $(7)$ : line of toxicity on exposure S.quadricauda to insecticide karate in concentration $(3) \mathrm{mg} / \mathrm{l}$ and $L T 50$ value 


\section{References:}

Abdel-Aty,A,M. ;El-Dib,M.A. and Badawy,M.I. (2006).Toxicity of pesticide industrial waste water to the green algae Scenedesmus obliquas : A case study. Pakistan J.of Bio. Sci., 9(3) : 563- 567.

- Anton ,F.A.; Laborda ,E. and Laborda ,P.(1993). Acut toxicity of technical captan to algae and fish. Bull. Environ. Ccontamin. Toxicol. , 50:392-399.

- Boutin , C.; Freemark, K.E. and Keddy ,C.J. (1993). Proposed guidline for registration of chemical pesticides: Non target plant testing and evaluation. Technical report series 145.Environment Canada, Ottawa , Ontario.

- Deneer,J.W.(2000).Toxicity of mixtures of pesticides in aquatic systems. Pestic. Manag. Sci. , 56: 516-520.

- Guillard,R.L. (1973). Culture methods and growth measurements. Hand book of phycology methods. Cambridge university press, Cambridge, pp.289-311.

- Hersh,C.M. and Crumpton , W.G.(1987). Determination of growth rate depression of some green algae by atrazine. Bull. Environ. Contamin. Toxicol. , 39: 10411048.

- Huang G.; Dai, S.G. and Sun, H.W.(1994). Determination of the toxicity of organic pollutants to algae. Environ. Chem., 13(3) :259-262.

Kasai, F.; Takamura, N. and Hatakeyama,A. (1993). Effects of smetryne on growth of various fresh water algal taxa. Environ.Pollut., 79:77-83.

- Kent,R.A. and Currie,D.(1995).Predicting algal sensitivity to a pesticide stress. Environ. Toxicol. Chem., 14:983-991.

Kong ,F.X. and Sang,W.L. (1999). Physiological and biochemical response of Scenedesmus obliquas to combined effect of $\mathrm{Al}, \mathrm{Ca}$, and low pH . Bull. Environ. Contamin. Toxicol. 62: 179-186.
Li, X.; Ping, X.; Xiemei ;Zhenbin, W. and Liqiang, X. (2005). Toxicity of Cypermethrin on growth, pigments, and superoxide dismutase of Scenedesmuse obliquas. Ecotoxcol.and Environ.Safety, 60: 188-192.

- Ma,J. and L iang,W.(2001). Acute toxicity of 12 herbicides to the green algae Scenedesmus obliquas and Chlorella pyrenoidosa to30 herbicides. Bull. Environ. Cotamin. Toxicol., 68:275-281.

- Prokhotskaya, V.Yu. ;Vesolova ,T.V.; Veselovskii, V.A. ;Dmitrieva,A.G. A. and Artyukhova, V.I. (2003). The dimensional -age structure of a laboratory population of Scenedesmus quadricauda (Turp.) Bereb. in the presence of imazalyl sulfate. Intern. J. Algae. ,5,82.

- Rand ,G.M.( 1995) .Fundamentals of aquatic toxicity : effects, environmental fate and risk assessment. $2^{\text {nd }}$ ed., Taylor and francis , Philadelphia.

- Solomon ,K.R. ;Baker, D.B. ;Richards, R.P. ; Klaine ,S.L.; Lapoint, T.W. ;Kendell, R.J.; Weisskopf ,C.P.; Giddings,J.M.; Giesy, J.P. ;Hall,L.w. and Williams ,W.M.( 1996) .Ecological risk assessment of atrazin in north America surface waters. Enivron. Toxicol. Chem. , 15:3176.

- Tang,J.X.; Hoagland, K.D. and Siegfried, B.D.( 1997). Differential toxicity of atrazine to selected fresh water algae. Bull. Environ. Contamin. Toxicol. , 59:631-637.

- U.S. EPA (1989). Sort -term methods for estimating the chronic toxicity of effluents and receiving water to fresh water organisms. $2^{\text {nd }}$ ed. EPA 1.2315:60014891001.

- Vag, M.C.; Kostopoulou, M.N.; Petsas, A.S.; Lalousi, M. E. ;Rasouli,Ch. And Lakkas,T.D. ( 2005) .Toxicity of organophosphorous pesticides to the marine algae Tetraselmis suecica. Global NEST Journal, 7(2): 222-227. 


\title{
Scenedesmus دراسة السمية الحادة للمبيد البايرثرويدي كراتي على طحلب المياه العذبة quadricauda (Turb.) Bersb
}

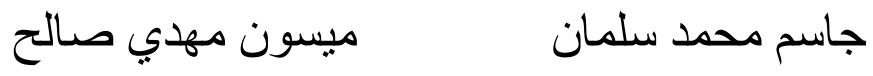 \\ قسم علوم الحياة- كلية العلوم- جامعة بابل
}

\begin{abstract}
الخلاصة:
Scenedesmuse تتاول البحث الحالي در اسة السمية قصيرة الأمد للمبيد الحشري كر اتي من خلال استخدام الطحلب الأخضر quadricauda

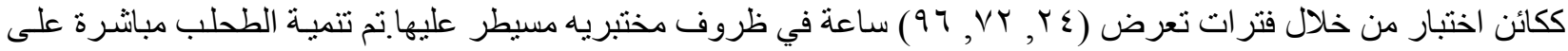
مـاء نهر جلبت مـن نهر الحلة بعد إمرار هـا خـلال ورق ترشيح(0 ـ , · ) مـايكروميتر لغرض التخلص من الطحالب و الأحياء المجهرية التي يحتمل وجودها فيها. استخدمت ثلاث تر اكيز من المبيد هي(0, • ) ( (1) و(r) ملغم /لتر وبثناث مكررات لكل تركيز وسجلت النتائج لكل ؟ كاعة من بداية التجربة. تضمنت الدر اسـة قياس الامتصاصية كمؤشر لكثافة الطحلب وحسبت عدد الخلايا ومعدل النمو ونسبة التثبيط وقيمة الزمن نصف القاتل. تبين إن التأثير يزداد بزيادة تركيز المبيد المستخدم وظهر إن عدد الخلايا ومعدل النمو يقل بزيادة فترة التعرض وزيادة التركيز المستخدم بينما كانت نسبة التنبيط نزداد بزيادة فترة التعرض و التركيز, وكانت أعلى نسبة تثبط هي( ع , (9\%)في التركيز ץ

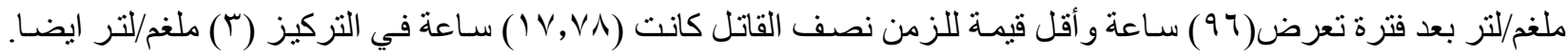
بينت نتائج الدر اسة إن تأثثر المبيد على معايير النمو والكثافة في الطحلب تحت الدراسـة يختلف تبعا للتر اكيز التي يتعرض لها وفترة التعرض.
\end{abstract}

